\title{
STRATEGI PEMBERDAYAAN MASYARAKAT \\ MELALUI PENGEMBANGAN DESA WISATA SEMANGAT BERTANI \\ DALAM UPAYA MENINGKATKAN KESEJAHTERAAN MASYARAKAT \\ DESA RAHARJA KECAMATAN TANJUNGSARI KABUPATEN SUMEDANG \\ PROVINSI JAWA BARAT
}

\author{
Oleh \\ Didi Supriadi \\ Institut Pemerintahan Dalam Negeri \\ supriadidi2323@gmail.com
}

\begin{abstract}
$T$ he tourism village as an alternative destination that highlights the lifestyle and quality of life of the people with its authenticity is also influenced by economic, physical and social conditions. This research focuses on the strategy of community empowerment through the development of Semangat Bertani Tourism Village in an effort to improve the welfare of the Raharja Village

Community. The purpose of this research is to develop a community empowerment strategy through development of very spirit tourist village in an effort to improve the welfare of the raharja village community, to analyze the inhibiting factors and to determine the efforts made in dealing with these inhibiting factors.

The research method used by the writer is descriptive method with a qualitative approach, technical data collection by observation, interview, and literature review analysis using SWOT analysis to find the strategy to be used. Based on the results of the study, an alternative strategy was produced so that it could be implemented and recommended to the Regional Government of Sumedang Regency and the Village Government of Raharja, namely: Performing arts and culture of the Raharja Village community routinely.

Based on the results of this study it was suggested to the Government of the Sumedang Regency to provide support for community empowerment in the Village of Raharja and immediately issue a Decree of the Regent of Sumedang regarding the designation of the Village of Raharja as a Tourism

Village. For the Office of Culture and Tourism to strengthen the role of the Tourism Awareness Group (Pokdarwis) and hold on going Education and Training for the people of Raharja Village so that community empowerment is more optimal in terms of tourism awareness.

Then for the Raharja Village Government to immediately make regulations that govern and support the community empowerment strategy through the Semangat Village Tourism Village in an effort to improve the welfare of the Raharja Village community and also provide understanding for the community of the benefits of very spirit tourist village Tourism Village in order to improve the welfare of the Raharja Village community.
\end{abstract}

Keywords: community empowerment, tourism village development, and community welfare 


\begin{abstract}
Abstrak
$\mathrm{D}$ esa wisata sebagai alternatif tujuan wisata yang menonjolkan pada gaya hidup dan kualitas hidup masyarakat dengan keasliannya juga dipengaruhi keadaan ekonomi, fisik dan sosial. Penelitian ini mengambil fokus pada strategi pemberdayaan masyarakat melalui Pengembangan Desa Wisata Semangat Bertani dalam upaya meningkatkan kesejahteraan Masyarakat Desa Raharja. Adapun Tujuan penelitian ini adalah untuk menyusun strategi pemberdayaan masyarakat melalui pengembangan Desa Wisata Semangat Bertani dalam upaya meningkatkan kesejahteraan masyarakat desa raharja, untuk menganalisis faktor-faktor penghambatnya dan untuk mengetahui upaya yang dilakukan dalam menangani faktor-faktor penghambat tersebut. Metode Penelitian yang penulis digunakan, yaitu metode deskriptif dengan pendekatan kualitatif, teknis pengumpulan data dengan observasi, wawancara, dan analisis peninjauan literatur dengan menggunakan analisis SWOT untuk mencari strategi yang akan digunakan.
\end{abstract}

Berdasarkan hasil penelitian, dihasilkan alternatif strategi agar dapat dilaksanakan dan direkomendasikan kepada Pemerintah Daerah Kabupaten Sumedang maupun Pemerintah Desa Raharja, yaitu: Penampilan kesenian dan kebudayaan masyarakat Desa Raharja secara rutin.

Berdasarkan hasil penelitian ini disarankan kepada Pemerintah Kabupaten Sumedang agar memberikan dukungan terhadap pemberdayaan masyarakat Desa Raharja dan segera menerbitkan Keputusan Bupati Sumedang tentang penetapan Desa Raharja menjadi Desa Wisata. Bagi Dinas Kebudayaan dan Pariwisata agar menguatkan peran Kelompok Sadar Wisata

(Pokdarwis) serta mengadakan Pendidikan dan Pelatihan yang berkelanjutan bagi masyarakat Desa Raharja agar pemberdayaan masyarakat lebih optimal dalam hal sadar wisata.

Kemudian bagi Pemerintah Desa Raharja agar segera membuat regulasi yang mengatur dan mendukung dalam strategi pemberdayaan masyarakat melalui Desa Wisata Semangat Bertani dalam upaya Meningkatkan kesejahteraan masyarakat Desa Raharja dan juga memberikan pengertian bagi masyarakat akan manfaat Desa Wisata Semangat Bertani guna meningkatkan kesejahteraan masyarakat Desa Raharja.

Kata kunci: pemberdayaan masyarakat, pengembangan desa wisata, dan kesejahteraan masyarakat

\section{PENDAHULUAN}

ekayaan alam dan budaya Indonesia

$\mathrm{K}_{\mathrm{s}}^{\mathrm{s}}$ seperti Pantai-Pantai di Bali, Lombok, Belitung, Gunung Semeru dan Bromo di Jawa Timur, Rinjani di Lombok, Keindahan pulau di Rajaampat, Taman Nasional di Sumatera, warisan budaya di Bali, Jogjakarta dan tempat-tempat lainnya merupakan beberapa contoh tempat wisata di Indonesia yang sering menjadi tujuan para wisatawan. Tempat-tempat wisata itu didukung dengan warisan budaya yang kaya yang mencerminkan sejarah dan keberagaman etnis Indonesia.

Otonomi Daerah diharapkan pemerintahan daerah dapat mandiri dalam mengelola semua potensi dan kekayaan yang ada di daerahnya sehingga dapat dioptimalkan menjadi salah satu cara yang menghasilkan sumber pendapatan dan pembiayaan kebutuhan daerah khususnya dalam pengembangan desa itu sendiri, Sebagaimana yang tercantum dalam UndangUndang Nomor 23 Tahun 2014 tentang Pemerintahan Daerah pasal 20 ayat (3) menyatakan bahwa: "urusan pemerintahan konkuren yang menjadi kewenangan daerah kabupaten/kota diselenggarakan sendiri oleh daerah kabupaten/kota atau dapat ditugaskan sebagian pelaksanaannya kepada desa."

Salah satu pendukung dari pembangunan nasional adalah sumber daya dan kekayaan alam dalam hal ini salah satunya adalah bidang pariwisata yang dikelola langsung oleh pemerintah daerah. 
Indonesia memiliki potensi yang sangat besar dalam hal pariwisata, dengan adanya pariwisata Indonesia dapat meningkatkan devisa atau pendapatan negara untuk mewujudkan kesejahteraan rakyat. Hal ini tertuang dalam

Undang-Undang Nomor 10 Tahun 2009 tentang Kepariwisataan yang menyatakan bahwa:"Pariwisata adalah berbagai macam kegiatan wisata yang didukung oleh berbagai fasilitas serta layanan yang disediakan oleh masyarakat, pengusaha, pemerintah, dan pemerintah daerah."

Provinsi Jawa Barat pun mempunyai potensi wilayah yang menjadi perhatian dalam hal ini tempat-tempat wisata yang diminati oleh wisata domestik dan mancanegara yang saat ini sedang mengembangkan desa wisata sekaligus untuk memberdayakan masyarakat dalam rangka meningkatkan kesejahteraan masyarakat, seperti halnya Kabupaten Sumedang yang merupakan salah satu kabupaten yang sedang berkembang di Provinsi Jawa Barat yang saat ini sedang

Melakukan terobosan-terobosan dalam mengembangkan pemerintahannya yang ada di bawahnya, dalam hal ini, yaitu: pemerintahan desa untuk memberdayakan masyarakat dengan potensi wilayah yang dimilikinya,

Dukungan dari pemerintah untuk hal tersebut di atas Kementerian Pariwisata dan Ekonomi Kreatif mengalokasikan dana kepada Pemerintah Provinsi Jawa Barat Rp 5,3 miliar untuk pengembangan desa wisata. Dukungan dari Kementerian Pariwisata dan Ekonomi Kreatif pada Pemerintah Provinsi Jawa Barat ini dalam pengembangan desa wisata khususnya Kabupaten Sumedang harus disambut baik untuk meningkatkan produktivitas dan kesejahteraan masyarakat.

Desa Wisata memiliki pengertian yang berbeda dengan desa maupun desa adat, desa adat belum tentu menjadi desa wisata begitu pula sebaliknya, desa wisata belum tentu berasal dari desa adat karena tidak semua desa adat dikomersialkan dalam bentuk kegiatan usaha pariwisata. Istilah desa adat dalam pengertian desa berbeda dengan desa wisata karena dalam UndangUndang Nomor 6 Tahun 2014

menyebutkan bahwa ketentuan desa adat adalah:

a. Kesatuan masyarakat hukum adat beserta hak tradisionalnya secara nyata masih hidup, baik yang bersifat teritorial, genealogis, maupun yang bersifat fungsional;

b. Kesatuan masyarakat hukum adat beserta hak tradisionalnya dipandang sesuai dengan perkembangan masyarakat; dan

c. Kesatuan masyarakat hukum adat beserta hak tradisionalnya sesuai dengan prinsip Negara Kesatuan

Republik Indonesia.

Desa wisata menurut Wiendu (1993:23) adalah sebagai berikut.

"Suatu bentuk integrase antara atraksi, akomodasi dan fasilitas pendukung yang disajikan dalam suatu struktur kehidupan masyarakat yang menyatu dengan tata cara dan tradisi yang berlaku. Atraksi adalah seluruh kehidupan keseharian penduduk setempat beserta setting fisik lokasi desa yang memungkinkan berintegrasi wisatawan sebagai partisipasi aktif seperti kursus tari, Bahasa dan lain-lain yang spesifik. Akomodasi adalah sebagian dari tempat tinggal penduduk setempat dana atau unit-unit yang berkembang atas konsep tempat tinggal penduduk."

Pelaksanaan Program Nasional Pemberdayaan Masyarakat tersebut Mengacu pada Peraturan Menteri Kebudayaan dan Pariwisata Nomor: KM.18/HM.001/ MKP/2011 tentang Pedoman Program Nasional Pemberdayaan Masyarakat (PNPM) Mandiri Pariwisata adalah suatu bentuk 
integrasi antara atraksi, akomodasi dan fasilitas pendukung yang disajikan dalam suatu Struktur kehidupan masyarakat yang menyatu dengan tata cara dan tradisi yang berlaku. Kementerian Pariwisata pada saat itu mengembangkan PNPM Mandiri Bidang Pariwisata dengan tujuan untuk meningkatkan kesejahteraan dan kesempatan kerja bagi masyarakat terutama masyarakat miskin melalui pengembangan desa wisata yang menargetkan untuk pengembangan dua ribu desa wisata.

Perwujudan dari pemberdayaan masyarakat yang dilaksanakan melalui penyaluran bantuan dana desa wisata kepada kelompok masyarakat yang bersifat stimulan dan dirancang untuk memberi kesempatan berusaha dalam kegiatan kepariwisataan. Penggunaan dana bantuan desa wisata diprioritaskan pada kegiatan kolektif dan langsung menyentuh masyarakat miskin.

Di Kabupaten Sumedang salah satu untuk meningkatkan Pendapatan Asli Daerah (PAD) adalah potensi pariwisata. Objek wisata yang terdapat di Kabupaten Sumedang di antaranya adalah Kampung Toga, Air Terjun Rendeng, Jatigede, Argowisata Cilembu, Taman wisata Pangjugjugan, Perkebunan teh, taman wisata Ciherang, Desa Wisata Semangat Bertani, dan lain sebagainya. Kabupaten Sumedang saat ini sedang memajukan desa-desa yang berpotensi untuk menjadi desa wisata. Menurut informasi yang penulis dapat dari Dinas Pariwisata dan Kebudayaan Kabupaten Sumedang, bahwa tujuan dari menjadikan desa wisata adalah untuk meningkatkan kesejahteraan masyarakat, tetapi masih banyak masyarakat yang kurang memahami hal tersebut, sehingga tidak memanfaatkan adanya desa wisata tersebut. Akan tetapi pemerintah Kabupaten Sumedang tidak menyerah untuk memberikan pengertian kepada masyarakat secara pelan-pelan.

Dari sekian banyak Objek wisata di Kabupaten Sumedang salah satunya adalah
Desa Wisata Semangat Bertani atau sering disebut dengan Desa Wisata Semangat Bertani. Desa Wisata Semangat Bertani merupakan singkatan dari Desa Wisata Semangat Bertani, di dalamnya juga terdapat Santosa Stable, yakni pelatihanpelatihan pertanian yang didukung oleh perguruan tinggi yang terkemuka yang dilaksanakan oleh mahasiswa seperti ITB, Unpad dan Unwim. Desa Wisata Semangat Bertani terletak di bawah lereng gunung batu, tepatnya di Cikandang, Desa Raharja Kecamatan Tanjungsari Kabupaten Sumedang. Desa Wisata Semangat Bertani merupakan Objek wisata yang menawarkan potensi wisata yang menonjolkan aktivitas bertani, pemandangan alam yang sangat indah dengan hamparan sawah yang luas, letaknya yang berada di lereng gunung batu, ekonomi kreatif yang di hasilkan oleh masyarakat, yaitu pengolahan pembuatan gula aren, budi daya jamur tiram, bertani, beternak, membuat anyaman dari bambu dan juga belajar kesenian. Keramahan masyarakat, membuat daya tarik tersendiri bagi wisatawan, kesenian, dan budaya yang di antaranya adalah adanya Kelompok Seni

Jentreng dan Seni Reak yang menjadi budaya Desa Raharja sejak dulu.

Kesejahteraan masyarakat di Desa Raharja masih tergolong rendah. Dengan adanya Desa Wisata Semangat Bertani (Dewi Semangat Bertani) diharapkan mampu meningkatkan kesejahteraan masyarakat Desa Raharja, akan tetapi masih terdapat berbagai kendala yang dihadapi dalam pencapaian kesejahteraan tersebut.

Kelompok Sadar Wisata yang kepengurusannya belum tertata dengan baik, karena anggota Pokdarwis masih menjadikan itu sebagai hal sampingan, belum menjadikan suatu tujuan untuk membantu dan meningkatkan kesejahteraan masyarakat. Pemerintah Kabupaten Sumedang masih belum optimal dalam membantu pembangunan sarana dan prasarana untuk mendukung daya Tarik wisatawan di lokasi wisata, contoh real 
pembangunan yang terjadi di sana, yaitu infrastruktur jalan menuju lokasi wisata yang masih jelek dan sempit. Sehingga yang menggunakan kendaraan beroda empat

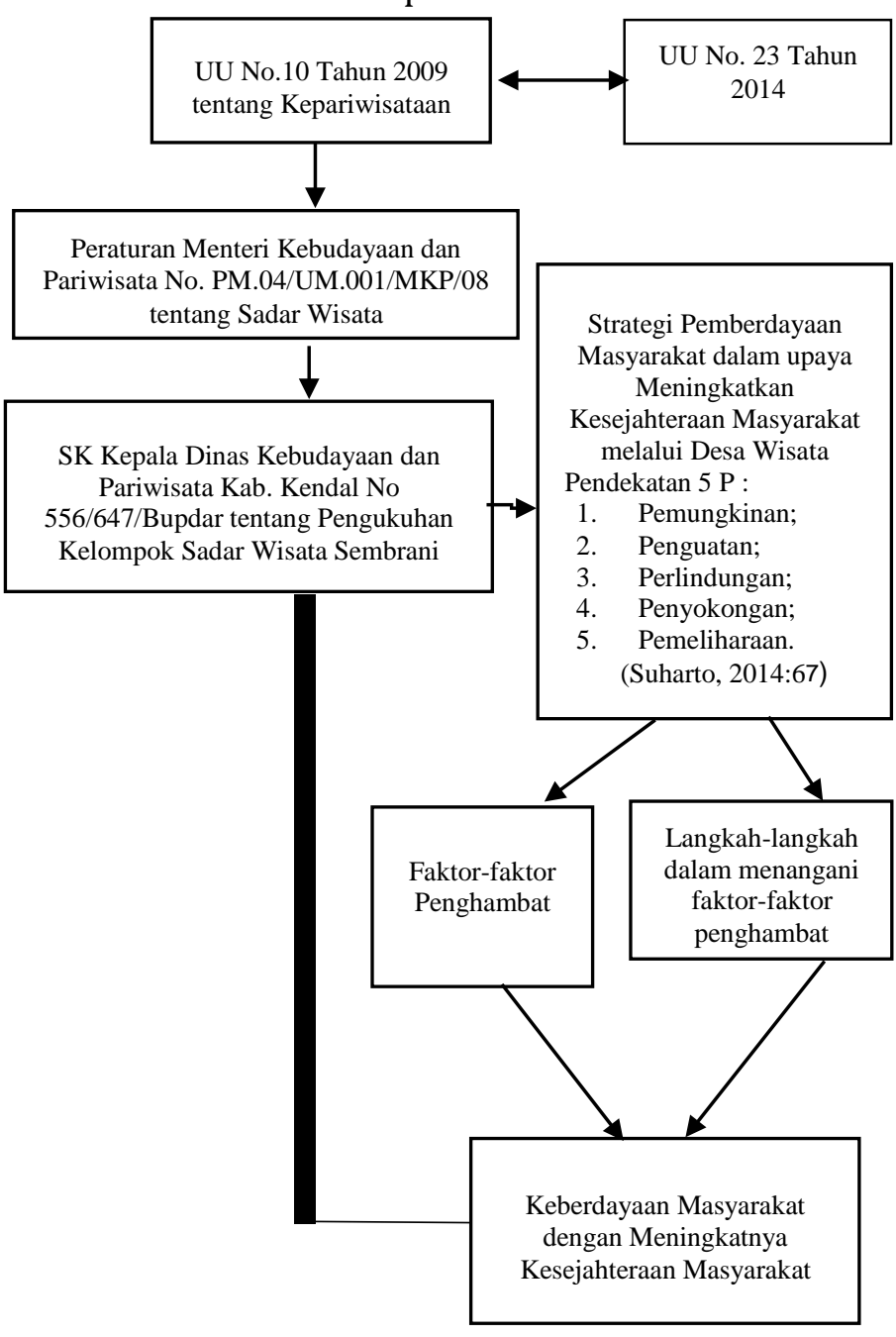

Gambar 1 Kerangka Pemikiran

sering kali berhimpit-himpitan dari arah yang berlawanan, belum lagi inisiatif dan partisipasi masyarakat dalam pembangunan jalan desa wisata masih sangat rendah yang menandakan bahwa masyarakat belum terlalu memahami pentingnya desa wisata guna membantu kesejahteraan masyarakat. Informasi tersebut penulis dapatkan dari Sekretaris Desa Raharja sebelum penulis melakukan penelitian secara langsung ke lapangan.

Berdasarkan penjelasan di atas, penulis merumuskan masalah sebagai berikut.
1. Bagaimana strategi pemberdayaan masyarakat melalui Desa WIsata

Semangat Bertani dalam meningkatkan 
Virioner - Vol. $12 \backslash$ No. 2\April 2020:387-404

meningkatkan kesejahteraan

masyarakat? 


\section{KAJIAN TEORETIS}

\section{Strategi}

Definisi Strategi menurut Chandler dalam Rangkuti 2006:4 bahwa: "Strategi adalah tujuan jangka panjang serta pendayagunaan dan alokasi semua sumber daya yang penting untuk mencapai tujuan tersebut". Kemudian menurut Bintoro Tjokroamidjojo (1998:13) bahwa "Strategi merupakan "perhitungan" mengenai rangkaian kebijaksanaan dan langkahlangkah pelaksanaan

Selanjutnya Menurut Rangkuti (2008:6) menyatakan bahwa "Analisis SWOT adalah suatu proses kreatif dalam merencanakan strategi, kebijakan dan program-program kerja suatu organisasi atau unit organisasi, dengan memperhatikan situasi dan kondisi lingkungan internal dan eksternal, baik pada sisi positif maupun negatif. Dengan kata lain

SWOT adalah identifikasi berbagai faktor secara sistematis untuk merumuskan strategi perusahaan dengan cara memaksimalkan kekuatan dan peluang, namun pada saat bersamaan dapat meminimalkan kelemahan dan ancaman. Sedangkan menurut Musa Hubeis dan Mukhamad Najib (2008:9496) mengukur strategi dapat dilakukan dengan menggunakan analisis SWOT

(Strength, Weakness, Opportunities, Threats) di mana strength, yaitu kekuatan, weakness, yaitu kelemahan, opportunities, yaitu peluang dan threats, yaitu ancaman. Dengan menggunakan analilis SWOT berbagai sudut pandang dalam melihat keterkaitan implikasi dari hubungan sehingga mudah menentukan suatu manufer, yaitu dengan mengaitkan analisis lingkungan internal dengan lingkungan eksternal terhadap strategi pemberdayaan masyarakat untuk meningkatkan kesejahteraan masyarakat melalui Desa Wisata. Terkait dengan analisis lingkungan tersebut, sebagaimana diungkapkan oleh Saleh (1999:47) bahwa:
Kedua jenis lingkungan internal dan eksternal ini secara impresif mempunyai pengaruh yang sangat kuat bagi keberlangsungan hidup suatu organisasi. Apabila sebuah organisasi tidak mampu membaca bahkan menguasai lingkungan maka eksistensi organisasi tersebut bisa terancam.

Tabel 1 Matriks SWOT

\begin{tabular}{|c|c|c|}
\hline $\begin{array}{l}\text { Faktor } \\
\text { Internal }\end{array}$ & $\begin{array}{l}\text { S T R E G H T S } \\
\text { (S)/ } \\
\text { D a ft a r } \\
\text { K e k u a t a n } \\
\text { Internal }\end{array}$ & $\begin{array}{l}\text { WEAKNESS } \\
(\mathbf{W}) / \\
\text { D a ft a r } \\
\text { Ke l e m a h a n } \\
\text { Internal }\end{array}$ \\
\hline $\begin{array}{l}\text { OPPORTU- } \\
\text { NITIES (0) } \\
\text { Daftar peluang } \\
\text { eksternal }\end{array}$ & $\begin{array}{l}\text { Startegi SO } \\
\text { Menggunakan } \\
\text { kekuatan } \\
\text { untuk } \\
\text { memanfaatka } \\
\text { n peluang } \\
\end{array}$ & $\begin{array}{l}\text { Strategi Wo } \\
\text { Meminimalka } \\
\text { n kelemahan } \\
\text { untuk } \\
\text { memanfaat- } \\
\text { kan peluang }\end{array}$ \\
\hline $\begin{array}{l}\text { THREATHS } \\
\text { (T) } \\
\text { Daftar } \\
\text { ancaman } \\
\text { eksternal }\end{array}$ & $\begin{array}{l}\text { Strategi ST } \\
\text { Menggunakan } \\
\text { kekuatan } \\
\text { untuk } \\
\text { mengatasi } \\
\text { ancaman }\end{array}$ & $\begin{array}{l}\text { Strategi WT } \\
\text { M e mi n i - } \\
\text { malkan dan } \\
\text { menghindari } \\
\text { ancaman. }\end{array}$ \\
\hline
\end{tabular}

Sumber: Rangkuti (2014:83)

Untuk menentukan strateginya sebuah isu dapat menggunakan teknik "Litmus Test". Litmus Test merupakan suatu teknik yang digunakan untuk menentukan bagaimana strategisnya isu tersebut. Pada teknik ini setiap isu strategis yang sudah teridentifikasi diberikan 10 pertanyaan yang kemudian akan diberikan penilaiannya. Isu yang memiliki skor tertinggi merupakan isu yang benar-benar strategis dan isu yang memiliki skor terendah merupakan isu operasional.

Penentuan skor dari isu-isu tersebut sebagai berikut.

a) Skor 1 = untuk isu yang bersifat operasional. 
b) Skor 2 = untuk isu yang cukup strategis.

c) Skor $3=$ untuk isu yang sangat strategis.

Dari hasil perkalian antara jumlah soal yang diperoleh nilai tertinggi 39 dan terendah 13, sehingga diterapkan kategorisasi sebagai berikut.

a) Nilai $13-21=$ isu kurang strategis

b) Nilai $22-30=$ isu cukup strategis

c) Nilai 31-39= isu sangat strategis

Suharto (2014:67) menyatakan bahwa pelaksanaan proses dan pencapaian tujuan pemberdayaan di atas dicapai melalui penerapan pendekatan pemberdayaan yang dapat disingkat menjadi 5P, yaitu:

1. Pemungkinan: menciptakan suasana atau iklim yang memungkinkan potensi masyarakat berkembang secara optimal. Pemberdayaan harus mampu membebaskan masyarakat dari sekatsekat structural dan kultural yang menghambat.

2. Penguatan: memperkuat pengetahuan dan kemampuan yang dimiliki masyarakat dalam memecahkan masalah dan memenuhi kebutuhankebutuhannya.

Pemberdayaan harus mampu menumbuhkembangkan segenap kemampuan dan kepercayaan diri masyarakat yang menunjang kemandirian mereka.

3. Perlindungan: melindungi masyarakat terutama kelompok lemah agar tidak tertindas oleh kelompok-kelompok kuat, menghindari persaingan yang tidak seimbang (apalagi tidak sehat) antara yang kuat dan lemah, dan mencegah terjadinya eksploitasi kelompok kuat terhadap kelompok lemah. Pemberdayaan harus diarahkan pada penghapusan segala jenis diskriminasi dan dominasi yang tidak menguntungkan masyarakat kecil.
4. Penyokongan: memberikan bimbingan dan dukungan agar masyarakat mampu menjalankan peranan dan tugastugas kahidupannya. Pemberdayaan harus mampu menyokong masyarakat agar tidak terjatuh ke dalam keadaan dan posisi yang semakin lemah dan terpinggirkan.

5. Pemeliharaan: memelihara kondisi yang kondusif agar tetap terjadi keseimbangan distribusi kekuasaan antara berbagai kelompok dalam masyarakat. Pemberdayaan harus mampu menjamin keselarasan dan keseimbangan yang memungkinkan setiap orang memperoleh kesempatan berusaha.

\section{Pemberdayaan Masyarakat}

Roesmidi (2006:11) menyatakan bahwa "secara etimologi kata pemberdayaan berasal dari kata daya yang artinya kekuatan, berdaya artinya bertenaga atau berkemampuan". Sementara itu, menurut Sedarmayanti, 2014:286 "Pemberdayaan berasal dari kata empowerment, yaitu "sesuatu peningkatan kemampuan yang sesungguhnya potensinya ada, dan usahanya adalah dari kurang berdaya menjadi lebih berdaya".

Edi Suharto (2014:47) mengemukakan pengertian masyarakat adalah sekelompok orang yang memiliki perasaan sama atau menyatu satu sama lain karena mereka saling berbagi identitas, kepentingan-kepentingan yang sama, perasaan memiliki dan biasanya satu tempat yang sama".

Tikson (2001) mengemukakan bahwa dalam proses pemberdayaan masyarakat terdapat beberapa kegiatan yang sangat penting dan perlu dilakukan agar masyarakat memiliki kemampuan baik secara individual maupun secara bersama-sama dalam suatu organisasi menuju pada suatu kemandirian, yaitu:

1. Capacity Building, yaitu kegiatan yang dilakukan untuk meningkatkan 
kemampuan masyarakat dalam hal keterampilan untuk bertindak dan bereaksi sesuai dengan situasi riil pada lingkungan di mana mereka berada.Bidang ini berkenaan dengan pengembangan kapabilitas anggota masyarakat yang menyangkut aspek nilai-nilai dan budaya yang memiliki daya motivasi seperti semangat kerja sama dan gotong royong.Di samping itu, mereka juga harus mampu melawan berbagai ketertinggalan di dalam realitas sosial dan ekonomi mereka.

2. Capacity Organizing, yaitu kegiatan yang berkenaan dengan peningkatan partisipasi masyarakat yang dapat dilakukan secara efektif melalui pengorganisasian ke dalam beberapa bentuk sesuai dengan kebutuhan/ kepentingan lokal sebagai alat untuk menyatakan kehendak mereka dan untuk memengaruhi proses perubahan yang dikehendaki.

3. Capacity Resources Management, yaitu kegiatan yang dilakukan agar masyarakat mampu mengelola sumber daya dengan baik, termasuk di dalamnya penentuan varietas sumber daya yang potensial untuk dikembangkan dan yang terpenting adalah kemampuan dalam mengambil keputusan dan bertanggung jawab secara bersama-sama

\section{Strategi Pemberdayaan Masyarakat}

Strategi pada dasarnya merupakan suatu alat atau cara untuk mencapai tujuan yang lebih baik. Dengan demikian strategi pemberdayaan masyarakat merupakan suatu alat atau cara untuk memberdayakan masyarakat.

I Nyoman Sumaryadi (2005:148-149) menyatakan bahwa:

Strategi program pengembangan masyarakat berorientasi pada pembangunan yang tercermin dalam empat generasi. Generasi pertama mengutamakan relief and welfare, yaitu dengan berusaha segera memenuhi kekurangan atau kebutuhan makanan, kesehatan dan pendidikan. Generasi kedua memusatkan kegiatannya pada small-scale reliant local development atau disebut dengan community development, yang antara lain meliputi pelayanan kesehatan, penerapan teknologi tepat guna, dan pembangunan infrastruktur. Dalam hal ini, penyelesaian persoalan masyarakat bawah (grassroot) tidak dapat diselesaikan dengan pendekatan atas bawah (top-down approach), melainkan membutuhkan pendekatan bawah atas (bottom-up approach). Kemudian, generasi ketiga adalah mereka yang terlibat dalam sustainable system development, mulai mempermasalahkan dampak pembangunan dan cenderung melihat jauh keluar daerahnya, ke tingkat regional, nasional dan internasional. Pada tahap ini terdapat usaha untuk memengaruhi perumusan kebijakan pembangunan. Strategi ini mengharapkan perubahan pada tingkat regional dan nasional. Sedangkan strategi keempat merupakan fasilitator gerakan masyarakat (people's movement). Hal ini dilakukan dengan membantu rakyat mengorganisasi diri, mengidentifikasi kebutuhan lokal dan memobilisasi sumber daya yang ada pada mereka. Generasi ini tidak sekedar hanya memengaruhi perumusan kebijakan saja, tetapi mengharapkan adanya perubahan dalam pelaksanaannya. Strategi pembangunan dari empat generasi ini kemudian harus dilengkapi dengan generasi kelima, yaitu pemberdayaan rakyat (empowering people). Pada era globalisasi dan perkembangan teknologi, masalah persaingan dan kerja sama menjadi isu penting. Generasi ini cenderung memperjuangkan ruang gerak yang lebih terbuka, dan untuk menciptakan pengakuan pemerintah terhadap arti penting inisiatif lokal. 


\section{Desa Wisata}

Muljadi (2009:27), menjelaskan bahwa:

"Desa Wisata sebagai suatu produk wisata yang melibatkan anggota masyarakat desa dengan segala perangkat yang dimilikinya". Desa wisata tidak hanya berpengaruh pada ekonominya, tetapi juga sekaligus dapat melestarikan lingkungan alam dan sosial budaya masyarakat terutama berkaitan dengan nilai-nilai kebersamaan, kekeluargaan, gotong royong, dan lainlain. Dengan demikian, kelestarian alam dan sosial budaya masyarakat akan menjadi daya tarik wisatawan yang melakukan perjalanan wisata. Selanjutnya inskeep memaparkan pariwisata perdesaan sebagai suatu bentuk pariwisata, di mana wisatawan tinggal di desa tersebut, kebanyakan masih tradisional dan jauh dari keramaian, wisatawan belajar mengenai budaya hidup dan tradisi masyarakat setempat dan sering terlibat dalam aktivitas masyarakat setempat.

Chafid Fandeli secara lebih komprehensif mengibaratkan desa wisata sebagai suatu wilayah perdesaan yang menawarkan keseluruhan suasana yang mencerminkan keaslian desa, baik dari segi kehidupan sosial budaya, adat istiadat, aktivitas keseharian, arsitektur bangunan, dan struktur tata ruang desa, serta potensi yang mampu dikembangkan sebagai daya Tarik wisata, misalnya atraksi, makanan dan minuman, cinderamata, penginapan, dan kebutuhan wisata lainnya.

\section{Kesejahteraan Masyarakat}

Kesejahteraan sosial memiliki beberapa makna yang relatif berbeda, meskipun substansinya sama. Edi Suharto menjelaskan (2014:2) bahwa kesejahteraan sosial pada intinya mencakup tiga konsepsi, yaitu:

1. Kondisi kehidupan atau keadaan sejahtera, yakni terpenuhinya kebutuhan-kebutuhan jasmaniah,

rohaniah, dan sosial.

2. Institusi, arena atau bidang kegiatan yang melibatkan lembaga kesejahteraan sosial dan berbagai profesi kemanusiaan yang menyelenggarakan usaha kesejahteraan sosial dan pelayanan sosial.

3. Aktivitas, yakni suatu kegiatan-kegiatan atau usaha yang terorganisir untuk mencapai kondisi sejahtera.

\section{METODE PENELITIAN}

Penelitian ini menggunakan metode deskriptif dengan pendekatan kualitatif. Menurut Nazir (2011: 54) memberikan pengertian bahwa "Metode deskriptif adalah suatu metode dalam meneliti status sekelompok manusia, suatu objek, suatu set kondisi, suatu sistem pemikiran, ataupun suatu kelas peristiwa pada masa sekarang". Tujuan dari penelitian deskriptif ini adalah untuk membuat deskripsi, gambaran atau lukisan secara sistematis, faktual dan akurat mengenai fakta-fakta, sifat-sifat serta hubungan antar fenomena yang diselidiki.

Kemudian Sugiyono (2011:9) memberikan pengertian tentang penelitian kualitatif di mana metode penelitian kualitatif adalah metode penelitian yang digunakan untuk meneliti pada kondisi objek yang alamiah, (sebagai lawannya adalah eksperimen) di mana peneliti adalah sebagai instrumen kunci, teknik pengumpulan data dilakukan secara triangulasi (gabungan), analisis data bersifat induktif/kualitatif, dan hasil penelitian kualitatif lebih menekankan makna dari pada generasi. Penelitian ini berusaha memberikan gambaran terkait strategi pemberdayaan masyarakat melalui Desa Wisata Semangat Bertani Dalam Upaya meningkatkan kesejahteraan masyarakat Desa Raharja.

Teknik pengumpulan data yang digunakan adalah: wawancara, dokumentasi, dan observasi serta triangulasi. Sedangkan 
informan berjumlah dalam penelitian ini berjumlah 44 orang terdiri dari Kepala Dinas Kebudayaan dan Pariwisata Kabupaten Sumedang, Kepala Desa Raharja, Sekretaris Desa Raharja, Ketua Kelompok Sadar Wisata, Masyarakat dan Wisatawan.

Teknik analisis data dalam penelitian ini, penulis menggunakan langkah-langkah analisis data menurut Miles dan Huberman dalam Sugiyono, (2011:246), yaitu data reduction, data display, dan conclusion drawing/verification. Berdasarkan hasil penelitian akan ditemukan faktor penentu baik faktor penghambat atau faktor pendukung kemudian akan dianalisis menggunakan anlisis SWOT Rangkuti (2006) sehingga menghasilkan strategi-strategi untuk menyusun upaya yang mungkin digunakan untuk mengatasi hambatan dalam startegi pemberdayaan masyarakat melalui Desa Wisata Semangat Bertani dalam Upaya Meningkatkan Kesejahteraan Masyarakat Desa Raharja.

\section{PEMBAHASAN}

\section{Startegi Pemberdayaan Masyarakat}

Berdasarkan teori pemberdayaan yang disebutkan oleh Suharto (2014:67) bahwa pelaksanaan proses dan pencapaian tujuan pemberdayaan dicapai melalui penerapan pendekatan pemberdayaan yang dapat disingkat menjadi 5P, yaitu:

1. Pemungkinan: menciptakan suasana atau iklim yang memungkinkan potensi masyarakat berkembang secara optimal. Pemberdayaan harus mampu membebaskan masyarakat dari sekatsekat struktural dan kultural yang menghambat.

2. Penguatan: memperkuat pengetahuan dan kemampuan yang dimiliki masyarakat dalam memecahkan masalah dan memenuhi kebutuhankebutuhannya.
Pemberdayaan harus mampu menumbuhkembangkan segenap kemampuan dan kepercayaan diri masyarakat yang menunjang kemandirian mereka.

3. Perlindungan: melindungi masyarakat terutama kelompok-kelompok lemah agar tidak tertindas oleh kelompokkelompok kuat, menghindari persaingan yang tidak seimbang (apalagi tidak sehat) antara yang kuat dan lemah, dan mencegah terjadinya eksploitasi kelompok kuat terhadap kelompok lemah. Pemberdayaan harus diarahkan pada penghapusan segala jenis diskriminasi dan dominasi yang tidak menguntungkan masyarakat kecil.

4. Penyokongan: memberikan bimbingan dan dukungan agar masyarakat mampu menjalankan peranan dan tugastugas kehidupannya. Pemberdayaan harus mampu menyokong masyarakat agar tidak terjatuh ke dalam keadaan dan posisi yang semakin lemah dan terpinggirkan.

5. Pemeliharaan: memelihara kondisi yang kondusif agar tetap terjadi keseimbangan distribusi kekuasaan antara berbagai kelompok dalam masyarakat. Pemberdayaan harus mampu menjamin keselarasan dan keseimbangan yang memungkinkan setiap orang memperoleh kesempatan berusaha.

Berdasarkan lima pendekatan tersebut, penulis melakukan wawancara guna mengetahui sejauh mana upaya-upaya yang telah dilakukan dalam upaya meningkatkan kesejahteraan masyarakat melalui desa wisata semangat bertani.

\section{a. Pemungkinan}

Pemungkinan adalah tahapan dalam menciptakan suasana atau iklim yang memungkinkan potensi masyarakat berkembang secara optimal sehingga masyarakat terbebas dari sekat-sekat 
struktural dan kultural yang menghambat dalam upaya meningkatkan kesejahteraan masyarakat melalui Desa Wisata Semangat bertani.

Berdasarkan wawancara penulis dengan Kepala Desa Raharja, Kusnadi, pada 2 Agustus 2019 pukul 10.00 WIB bertempat di Ruang Kepala Desa Raharja, beliau menyampaikan bahwa,

"Usaha wisata yang dilakukan di Desa Raharja sudah dimulai sejak tahun 2014 dengan warga masyarakat sudah memulai memproduksi souvenir, kerajinan tangan dan makanan khas untuk diasong di Desa Wisata Semangat Bertani dan Santosa Stable."

Dapat disimpulkan bahwa usaha wisata di lingkungan masyarakat Desa Raharja sudah sekitar dua tahun berjalan di mana masyarakat mulai memanfaatkan keahlian dan keterampilan untuk dijual di tampailkan.

Timbulnya semangat masyarakat Desa Raharja untuk bergelut di bidang usaha wisata dikarenakan lokasi desa tersebut telah dijadikan Desa Wisata dan telah diresmikan langsung oleh Bupati Kabupaten Sumedang. Pada akhirnya terbentuklah kelembagaan dari Dinas Kebudayaan dan Pariwisata Kabupaten Sumedang, yaitu Kelompok Sadar Wisata (Pokdarwis), kelompok tersebut bertanggung jawab atas kemajuan Desa Wisata Semangat bertani, dan juga terbitnya SK Desa Wisatapun tergantung kepada Pokdarwis.

\section{b. Penguatan}

Penguatan merupakan usaha untuk memperkuat pengetahuan dan kemampuan yang dimiliki masyarakat dalam memecahkan masalah dan memenuhi kebutuhankebutuhannya serta menumbuhkembangkan segenap kemampuan dan kepercayaan diri masyarakat yang menunjang kemandirian dalam berusaha wisata.
Berdasarkan wawancara penulis dengan Kepala Dinas Pariwisata Kabupaten Sumedang pada 3 Agustus 2019 pukul 09.30 WIB bertempat di ruang kerja beliau:

Disbudpar Kabupaten Sumedang membentuk Kelompok Sadar Wisata (Pokdarwis), kemudian melakukan pembinaan kepada kelompok tersebut, salah satu tujuan Pokdarwis itu adalah untuk meningkatkan kesejahteraan masyarakat di desa Raharja melalui Desa Wisata Semangat bertani,

Disbudpar juga telah menyelenggarakan beberapa kegiatan diklat guna mendukung pengembangan Desa Wisata tersebut sehingga dapat membantu perekonomian masyarakat setempat. Salah satunya juga perwakilan dari Dinas Pariwisata Kabupaten Sumedang sering meninjau Desa Wisata tersebut dan memberikan penyuluhan untuk mengembangkan desa tersebut, antara lain dengan cara mengembangkan home stay, kerajinan tangan dan juga makanan khas yang dimiliki Desa Raharja. Pemerintah juga memberikan kesempatan seluas-luasnya kepada Desa untuk mengembangkan Desa Wisata tersebut. Pokdarwis tersebut juga memuat Kelompok Wanita Tani (KWT), karena Desa Wisata Semangat Bertani menonjolkan dalam bidang Bertani.

Berdasarkan pernyataan di atas, dapat disimpulkan bahwa sudah ada upaya dalam penguatan pengetahuan dan kemampuan masyarakat dalam rangka meningkatkan kesejahteraan masyarakat melalui Desa Wisata Semangat Bertani oleh Pemerintah daerah, yaitu Dinas Kebudayaan dan Pariwisata. Akan tetapi masih terdapat keluhan dari masyarakat Desa Raharja seperti yang disampaikan oleh Sekretaris Desa Raharja, Siti Mahmudah, dalam kesempatan wawancara dengan penulis pada 4 Agustus 2019 pukul 08.30 WIB.

Dalam setiap penyuluhan yang diselenggarakan oleh instansi-instansi 
terkait mengenai desa wisata tersebut, pada akhirnya tidak berkelanjutan dan tidak maksimal dalam

penyelenggaraannya karena instansiinstansi tersebut tidak secara optimal membantu masyarakat. Bahkan sempat mendatangkan mahasiswa dari Sekolah Pariwisata untuk magang di Desa Wisata tersebut tapi hasilnya pun tidak optimal.

\section{c. Perlindungan}

Perlindungan dalam hal ini adalah upaya untuk melindungi masyarakat terutama kelompok-kelompok lemah agar tidak tertindas oleh kelompok-kelompok kuat atau dengan kata lain adalah upaya penghapusan segala jenis diskriminasi dan dominasi yang tidak menguntungkan masyarakat kecil.

Dinas Kebudayaan dan Pariwisata Kabupaten Sumedang telah membentuk Kelompok Sadar Wisata (Pokdarwis) yang diharapkan mampu menjadi wadah yang salah satu fungsinya adalah sebagai fungsi perlindungan seperti yang dijelaskan di atas, akan tetapi belum adanya kesamaan persepsi antara Pokdarwis dengan masyarakat dalam mengelola Desa Raharja menyebabkan sampai saat ini fungsi Pokdarwis belum terlaksana secara maksimal, hal tersebut sesuai dengan penyampaian Ketua Pokdarwis, Agung, dalam kesempatan Wawancara dengan penulis pada 4 Agustus 2019 pukul 13.00 WIB bertempat di kediaman beliau bahwa:

Pokdarwis diharapkan mampu menjadi wadah untuk masyarakat pelaku usaha wisata guna meningkatkan kesejahteraan masyarakat melalui desa wisata Semangat Bertani tersebut akan tetapi belum adanya kesepahaman antara desa dan masyarakat menjadikan fungsi Pokdarwis belum maksimal karena masyarakat berpikir bahwa Pokdarwis hanya akan mengurangi jumlah pendapatannya.
Berdasarkan penjelasan tersebut, dapat disimpulkan bahwa sudah ada upaya dalam melindungi kelompok-kelompok kecil agar tidak ada diskriminasi dan dominasi oleh kelompok-kelompok kuat, yaitu dengan dibentuknya Pokdarwis, akan tetapi fungsi Pokdarwis yang belum maksimal membuat belum ada jaminan atas perlindungan tersebut karena anggota dari Pokdarwis pun belum maksimal dalam menjalankan tanggung jawabnya.

\section{d. Penyokongan}

Penyokongan merupakan upaya untuk memberikan bimbingan dan dukungan agar masyarakat mampu menjalankan peranan dan tugas dalam perannya masing-masing.

Berdasarkan wawancara penulis dengan Kepala Dinas Kebudayaan dan Pariwisata Kabupaten Sumedang padaSelasa, 3 Agustus 2019 pukul 09.30 WIB bertempat di ruang kerja beliau:

Disbudpar dalam upaya pengembangan desa wisata, khususnya Desa Raharja telah membentuk Pokdarwis dan telah memberikan pelatihan serta Pembinaan kepada Anggota Pokdarwis guna mendukung peningkatan kesejahteraan masyarakat melalui Desa Wisata Semangat Bertani antara lain diklat homestay, pelatihan keterampilan membatik dan pelatihan membuat website.

Berdasarkan hasil wawancara tersebut, dapat disimpulkan bahwa sudah ada usaha dari Pemerintah Daerah untuk menyokong masyarakat agar memiliki keterampilan untuk memajukan Desa Wisata Semangat Bertani dan akhirnya dapat membantu meningkatkan kesejahteraan masyarakat tersebut.

\section{e. Pemeliharaan}

Pemeliharaan dalam hal ini adalah upaya untuk memelihara kondisi agar tetap terjadi 
keseimbangan dan keselarasan yang memungkinkan setiap orang untuk memperoleh kesempatan berusaha.

Desa Raharja seperti apa yang dijelaskan pada pendekatan sebelumnya telah membentuk Kelompok Sadar Wisata (Pokdarwis) yang diharapkan mampu menjadi wadah yang salah satu fungsinya adalah sebagai fungsi pemeliharaan seperti yang dijelaskan di atas, akan tetapi belum adanya kesamaan persepsi antara Pokdarwis dengan masyarakat dalam mengelola Desa Raharja menyebabkan sampai saat ini fungsi Pokdarwis belum terlaksana secara maksimal, hal tersebut sesuai dengan penyampaian Ketua Pokdarwis, Agung, dalam kesempatan wawancara dengan penulis pada 4 Agustus 2019 pukul 13.00 WIB di kediaman beliau bahwa:

Pokdarwis diharapkan mampu menjadi wadah untuk masyarakat pelaku usaha wisata guna meningkatkan kesejahteraan masyarakat melalui desa wisata Semangat Bertani akan tetapi belum adanya kesepahaman antara desa dan masyarakat menjadikan fungsi Pokdarwis belum maksimal karena masyarakat berpikir bahwa Pokdarwis hanya akan mengurangi jumlah pendapatannya.

Berdasarkan wawancara penulis dengan Kepala Desa Raharja, Kusnadi, pada 2 Agustus 2019 pukul 10.00 WIB yang bertempat di Ruang Kerja Kepala Desa, beliau menyampaikan bahwa, "Saya mempunyai harapan dengan adanya Desa Wisata Semangat Bertani di Desa Raharja ini, seluruh masyarakat dapat merasakan hasil dari usaha-usaha wisata yang ada di Desa Raharja ini, sehingga dapat membantu perekonomian masyarakat tentunya meningkatkan kesejahteraan masyarakat Desa Raharja itu sendiri." Selain itu, beliau juga menyampaikan bahwa:

Kami berharap Pokdarwis dapat merangkul seluruh warga masyarakat untuk dapat memanfaatkan Desa Wisata Semangat Bertani sebagai peluang untuk mereka menambah rezeki sehingga dapat membantu perekonomian masyarakat, sehingga kesejahteraan masyarakat Desa Raharja dapat meningkat.

Sejalan dengan penyampaian Kepala Desa Raharja, Ketua Pokdarwis, Agung, pada kesempatan wawancara dengan beliau pada 4 Agustus 2019 pukul 13.00 WIB bertempat di kediaman beliau:

Pokdarwis diharapkan mampu menjadi wadah masyarakat untuk meningkatkan kesejahteraan melalui Desa Wisata Semangat Bertani akan tetapi belum adanya kesepahaman antara desa dan masyarakat menjadikan fungsi Pokdarwis belum maksimal karena masyarakat berpikir bahwa Pokdarwis hanya akan mengurangi jumlah pendapatannya.

Hal tersebut juga sejalan dengan harapan Pemerintah Daerah Kabupaten Sumedang dalam hal ini Dinas Kebudayaan dan Pariwisata, dalam kesempatan wawancara dengan Kepala Dinas Kebudayaan dan Pariwisata Kabupaten Sumedang pada 3 Agustus 2019 pukul 09.30 WIB bertempat di ruang kerja beliau,

"Disbudpar berusaha mengembangkan desa-desa di Kabupaten Sumedang yang memiliki potensi, untuk membantu meningkatkan kesejahteraan masyarakat yang menonjolkan makanan, kesenian dan kebudayaan khas daerah."

Berdasarkan hasil klasifikasi beberapa strategi tersebut di atas, diketahui urutan prioritas strategi yang dibutuhkan untuk pemberdayaan masyarakat melalui Desa Wisata Semangat Bertani dalam upaya meningkatkan kesejahteraan masyarakat Desa Raharja. Program yang memiliki skor tertinggi adalah program Mengikuti Festival Desa Wisata yang diadakan oleh pemerintah. 
Program tersebut memerlukan biaya yang cukup besar dan persiapan sarana prasarana pendukung guna menampilkan stand desa wisata yang menarik. Sedangkan program yang dapat segera dilaksanakan oleh pemerintah desa adalah program penampilan kesenian dan kebudayaan Desa Raharja secara rutin. Hal ini ditunjukkan dengan hasil litmus test yang programprogram tersebut mendapatkan skor lebih rendah yang berarti dapat dilakukan segera agar menarik wisatawan untuk berkunjung ke Desa Wisata Semangat bertani, maka secara tidak langsung akan membantu meningkatkan kesejahteraan masyarakat desa Raharja dengan banyaknya wisatawan yang berkunjung ke Desa Wisata Semangat bertani.

\section{Faktor-Faktor Penghambat}

Berdasarkan hasil penelitian, ditemukan beberapa penghambat dalam pelaksanaan dalam upaya peningkatan kesejahteraan masyarakat melalui Desa Wisata Semangat bertani, antara lain:

\section{a. Minimnya perhatian Pemerintah Daerah}

Meskipun pariwisata menjadi salah satu prioritas dalam rencana pembangunan menengah daerah, akan tetapi realisasi yang dirasakan terutama dalam peningkatan kesejahteraan masyarakat melalui Desa Wisata Semangat Bertani belum begitu terasa khususnya terkait bantuan secara finansial. Pemerintah Daerah Disbudpar dalam hal ini masih sedikit dalam membantu masalah pendanaan, Dinas kebudayaan dan pariwisata baru bias membantu pendanaan jika dalam even Gelar Budaya yang dilaksanakan ketika hari lahir Kabupaten Sumedang. Sedangkan dalam even lain atau kegiatan lainnya justru kami berusaha untuk mencari bantuan pendanaan ke pihak lain, seperti pengusaha pelatihan-pelatihan pertanian dari Semarang.

\section{b. Kegiatan Pendidikan dan Pelatihan yang tidak berkelanjutan}

Bantuan dalam bentuk pendidikan dan pelatihan yang menunjang peningkatan kesejahteraan masyarakat melalui Desa Wisata Semangat Bertani belum mampu diberikan oleh Pemerintah Daerah secara berkelanjutan. Beberapa kali pernah diselenggarakan diklat, akan tetapi tidak pernah dipantau sejauh mana pengaruh dari output dan outcome dari kegiatan diklat tersebut serta tidak diselenggarakan secara rutin sehingga tidak ada pemerataan kualitas sumber daya manusia yang ada dan cenderung tidak ada manfaat yang terasa.

Hal tersebut sejalan dengan pernyataan Kepala Desa Raharja, Kusnadi dalam kesempatan wawancara dengan penulis pada 2 Agustus 2019 pukul 10.00 WIB bertempat di Ruang Kepala Desa Raharja,

"Dalam setiap diklat yang diadakan baik oleh Disbudpar kami selalu kirimkan perwakilan masyarakat untuk mengikuti diklat tersebut, akan tetapi diklat yang diselenggarakan tidak berkelanjutan dan cenderung insidental saja."

\section{c. Perbedaan persepsi tujuan pembentukan Pokdarwis}

Pembentukan Kelompok Sadar Wisata (Pokdarwis) diharapkan mampu mengelola usaha wisata dalam rangka peningkatan kesejahteraan masyarakat melalui Desa Wisata Semangat bertani, akan tetapi belum adanya kesamaan persepsi antara Pokdarwis dengan masyarakat dalam mengelola Desa Wisata Semangat Bertani menyebabkan sampai saat ini usaha wisata di lingkungan Desa Wisata Semangat Bertani masih berjalan secara mandiri tanpa ada campur tangan Pokdarwis, dikarenakan masyarakat berpikiran bahwa dengan dibentuknya Pokdarwis pendapatan masyarakat pelaku usaha wisata akan berkurang karena harus bagi hasil dengan Pemerintah Desa sehingga 
Desa Raharja belum dapat berkembang menjadi Desa Wisata secara utuh.

Hal tersebut dibenarkan oleh Ketua Pokdarwis, Agung, dalam kesempatan wawancara dengan penulis pada 4 Agustus 2019 pukul 13.00 WIB bertempat di kediaman beliau:

"Kami belum dapat mengumpulkan seluruh masyarakat pelaku usaha wisata dikarenakan mereka masih saja berpikiran bahwa Pokdarwis akan mengurangi jumlah pendapatan mereka karena harus ada bagi hasil antara mereka kepada Desa."

\section{d. Banyaknya investor yang menguasai lahan}

Belum adanya peraturan yang mengatur tentang mekanisme investor dalam membeli maupun menggunakan lahan di area Desa Raharja menyebabkan banyaknya warga masyarakat yang menjual secara mandiri kepada para investor, hal tersebut ditakutkan semakin lama akan semakin banyak pihak luar yang membuka usaha wisata dan warga masyarakat hanya akan menjadi buruh atau karyawan di tempat tersebut. Kepala Desa Raharja, Kusnadi dalam kesempatan wawancara dengan penulis pada 2 Agustus 2019 pukul 10.00 WIB bertempat di Ruang Kepala Desa Raharja menguatkan pernyataan tersebut bahwa:

Banyak masyarakat yang tergiur untuk menjual tanahnya kepada para investor untuk memenuhi kebutuhannya, hal tersebut sangat disayangkan karena Pemerintah Desa juga tidak dapat campur tangan karena sampai sekarang memang belum ada Peraturan Desa yang mengatur hal tersebut.

\section{Upaya yang Dilakukan}

Berdasarkan kendala-kendala yang dijelaskan di atas dan hasil penelitian penulis, Pemerintah Desa Raharja mampu bertahan dan menghadapi segala kendala yang ada dengan langkah-langkah sebagai berikut.

\section{a. Minimnya Perhatian Pemerintah Daerah}

Berdasarkan wawancara penulis dengan Kepala Desa Raharja, Kusnadi, pada 2 Agustus 2019 pukul 10.00 WIB yang bertempat di Ruang Kepala Desa Raharja, beliau menjelaskan bahwa:

Meskipun perhatian Pemerintah Daerah masih minim, Pemerintah Desa Raharja tetap berjuang dalam upaya peningkatan kesejahteraan masyarakat melalui Desa Wisata Semangat Bertani menjalin kerja sama dengan pengusaha untuk peningkatan sumber daya sehingga pengusaha tersebut meminjamkan dan memberikan modal untuk kemajuan

Desa Wisata tersebut.

Berdasarkan keterangan tersebut, dapat disimpulkan bahwa meskipun dukungan dari Pemerintah Daerah masih minim, akan tetapi Desa Raharja tetap mengusahakan dukungan-dukungan dari pihak ketiga, yaitu Pengusaha Mengadakan pelatihan bidang pertanian sebagai penyedia peminjaman modal untuk memajukan dan mewujudkan Desa Wisata Semangat bertani.

\section{b. Kegiatan Pendidikan dan Pelatihan yang tidak berkelanjutan}

Berdasarkan wawancara penulis dengan Kepala Desa Raharja, Kusnadi, pada 2 Agustus 2019 pukul 10.00 WIB yang bertempat di Ruang Kepala Desa Raharja, beliau menjelaskan bahwa:

Kegiatan pendidikan dan pelatihan yang diselenggarakan oleh pihak-pihak tertentu selalu dimanfaatkan dengan baik dengan mengirimkan perwakilan masyarakat guna meningkatkan kompetensi serta mendukung dalam peningkatan kesejahteraan melalui Desa Wisata Semangat bertani. 
Berdasarkan keterangan tersebut, dapat diketahui bahwa meskipun penyelenggaraan diklat masih minim dan belum berkelanjutan, akan tetapi Desa Raharja selalu mengirimkan perwakilan masyarakatnya guna meningkatkan kompetensi sumber daya manusia dalam upaya peningkatan kesejahteraan masyarakat melalui Desa Wisata Semangat bertani.

\section{c. Perbedaan Persepsi dalam pembentukan Pokdarwis}

Berdasarkan wawancara penulis dengan Ketua Pokdarwis, Agung, pada 4 Agustus 2019 pukul 13.00 WIB yang bertempat di kediaman beliau:

Pokdarwis dibentuk dengan tujuan mampu mengelola seluruh pelaku usaha wisata guna meningkatkan kesejahteraan masyarakat melalui Desa Wisata, akan tetapi sebagian masyarakat pelaku usaha wisata masih ragu untuk segera mendukung tujuan tersebut dikarenakan takut pendapatannya berkurang karena harus bagi hasil dengan Pemerintah Desa. Oleh karena itu, Pokdarwis dalam menjalankan fungsinya sekarang dimulai dengan sekedar mendata jumlah pengunjung di setiap pelaku usaha wisata dan memulai mengembangkan beberapa lahan milik desa menjadi lahan untuk usaha wisata, yaitu pengembangan mata air dan lahan di persawahan yang mempunyai lokasi yang strategis untuk menikmati pemandangan perdesaan, sembari meyakinkan kepada seluruh masyarakat pelaku usaha wisata agar dapat segera bergabung dan meningkatkan kesejahteraan melalui Desa Wisata Semangat bertani.

Berdasarkan penjelasan tersebut, dapat disimpulkan bahwa sembari meyakinkan masyarakat pelaku usaha wisata, Pokdarwis memulai langkahnya dengan mendata jumlah wisatawan yang berkunjung di setiap pelaku usaha wisata di Desa Raharja untuk mengetahui perkembangan daya tarik Desa
Wisata Semangat Bertani dan memulai mengembangkan lahan milik desa menjadi usaha wisata, yaitu pengembangan persawahan dan juga aliran mata air pegunungan yang strategis untuk menikmati suasana perdesaan.

\section{d. Banyaknya Investor yang menguasai lahan}

Berdasarkan wawancara penulis dengan Kepala Desa Raharja, Kusnadi, pada 2 Agustus 2019 pukul 10.00 WIB yang bertempat di Ruang Kepala Desa Raharja, beliau menjelaskan bahwa:

Banyaknya investor yang membeli lahan-lahan milik masyarakat ditakutkan semakin lama masyarakat hanya kan menjadi buruh atau karyawan di tanah sendiri, seharusnya hal tersebut dapat dicegah atau dikurangi dengan menerbitkan peraturan desa yang mengatur tentang mekanisme masuknya investor di lingkungan Desa Raharja.

Berdasarkan keterangan tersebut, dapat disimpulkan bahwa sebenarnya permasalahan investor yang bebas masuk dan membeli lahan di Desa Raharja dapat diselesaikan dengan menerbitkan peraturan desa tentang mekanisme jual beli lahan atau masuknya investor di lingkungan Desa Raharja, akan tetapi hal tersebut belum dapat dilaksanakan karena belum adanya inisiasi dari Pemerintah Desa sendiri. Oleh karena itu, untuk mengurangi investor masuk ke desa, Pemerintah Desa Raharja masih hanya sebatas menghimbau kepada masyarakat agar dapat memaksimalkan sumber daya alam yang ada untuk digunakan sebagai modal utama berusaha wisata.

\section{SIMPULAN}

Berdasarkan hasil wawancara penulis dengan informan dan tinjauan literatur yang dilakukan serta hasil analisis deskriptif dengan menggunakan analisis SWOT, maka dapat disimpulkan beberapa hal sebagai berikut. 
Pertama, strategi pemberdayaan masyarakat yang dapat dilakukan melalui Desa Wisata Semangat Bertani dalam upaya meningkatkan kesejahteraan masyarakat Desa Raharja berdasarkan hasil analisis SWOT dan litmus tes, Strategi yang sangat strategis untuk dilaksanakan adalah Penampilan kesenian dan kebudayaan masyarakat Desa Raharja secara rutin; sedangkan yang kurang strategis untuk dilaksanakan saat ini, yaitu Mengikuti Festival Desa Wisata yang diadakan oleh Pemerintah.

Kedua, faktor-faktor penghambat strategi pemberdayaan masyarakat melalui Desa Wisata Semangat Bertani dalam upaya meningkatkan kesejahteraan masyarakat adalah:

1. Minimnya perhatian Pemerintah Daerah

2. Kegiatan Pendidikan dan Pelatihan yang tidak berkelanjutan

3. Perbedaan persepsi tujuan pembentukan Pokdarwis

4. Banyaknya investor yang menguasai lahan.

Ketiga, upaya yang dilakukan dalam menangani faktor-faktor penghambat strategi pemberdayaan masyarakat melalui Desa Wisata Semangat Bertani dalam upaya meningkatkan kesejahteraan masyarakat adalah:

1. Mencari dukungan dari pihak ketiga, yaitu Pengusaha Pelatihan-pelatihan pertanian dan dari Dinas Pertanian sebagai penyedia peminjaman modal.

2. Mengirimkan perwakilan masyarakat dalam setiap kesempatan pendidikan dan pelatihan guna meningkatkan kompetensi sumber daya manusia dalam upaya peningkatan kesejahteraan masyarakat melalui Desa Wisata

Semangat bertani.

3. Menghimbau kepada masyarakat agar dapat memaksimalkan sumber daya alam yang ada dan memanfaatkan adanya Desa Wisata Semangat Bertani sebagai wadah untuk meningkatkan kesejahteraan masyarakat Desa Raharja sendiri dan untuk digunakan sebagai modal utama berusaha wisata.

\section{SARAN}

Berkaitan dengan simpulan di atas, maka penulis mengemukakan beberapa saran antara lain:

Pertama, Pemerintah Kabupaten Sumedang agar lebih memperhatikan dan memberikan dukungan terhadap pemberdayaan masyarakat melalui Desa Wisata Semangat Bertani dalam upaya meningkatkan kesejahteraan masyarakat Desa Raharja.

Kedua, Dinas Kebudayaan dan Pariwisata dalam menyelenggarakan kegiatan pendidikan dan pelatihan agar semakin banyak sumber daya manusia yang mempunyai kompetensi dan mempercepat peningkatan kesejahteraan masyarakat dengan meningkatnya peran Desa Wisata Semangat Bertani di Desa Raharja. Dinas Kebudayaan dan Pariwisata agar ikut menguatkan peran Kelompok Sadar Wisata (Pokdarwis) dalam meningkatkan kesejahteraan masyarakat melalui pengembangan Desa Wisata Semangat bertani.

Ketiga, Pemerintah Desa Raharja agar segera membuat regulasi yang mengatur dan mendukung dalam strategi pemberdayaan masyarakat melalui

Pengembangan Desa Wisata Semangat Bertani dalam upaya peningkatan kesejahteraan masyarakat Desa Raharja. dan juga membantu memberikan pengertian kepada masyarakat untuk memanfaatkan adanya Desa Wisata Semangat Bertani sebagai lahan usaha untuk meningkatkan kesejahteraan masyarakat Desa Raharja.

\section{DAFTAR PUSTAKA}


A.J. Muljadi. 2009. Kepariwisataan dan Perjalanan. Jakarta: PT Raja Grafindo Persada.

Arikunto, Suharsimi. 2006. Prosedur Penelitian: Suatu Pendekatan Praktik. Jakarta: Asdi mahasatya.

Arikunto, S. 2010. Prosedur penelitian: Suatu Pendekatan Praktik. (Edisi Revisi). Jakarta: Rineka Cipta.

Bungin, Burhan. 2009. Penelitian Kualitatif. Jakarta: Kencana.

Bryson, John M. 1999. Perencanaan Strategis Bagi Organisasi Sosial.

Arikunto, S 2008. Perencanaan Strategis Bagi Organisasi Sosial. Jakarta: Pustaka Pelajar.

Effendy, Onong Uchjana. 2008. Dinamika

Komunikasi. Bandung:
Remaja
Rosdakarya.

Fandeli, Chafid. 2002. Perencanaan Kepariwisataan Alam. Yogyakarta: Fakultas Kehutanan Universitas Gajah Mada.

Hatten, Kenneth J dan Mary Louise Hatten. 1988.Effective Strategic Management. Englewood Cliffs: Prentice Hall.

Hubeis, Musa dan Najib, Mukhamad. 2008.

Manajemen Strategis dalam Pengembangan Daya Saing Organisasi. Bogor: PT Elex Media Komputindo.

Kartasasmita, Ginanjar. 1996. Pembangunan Untuk Rakyat: Memadukan Pertumbuhan dan Pemerataan. Jakarta: Pustaka Cidessindo.

Labolo, Muhadam. 2008. Memahami Ilmu Pemerintahan. Jakarta: Raja Grafindo Persada.

Marrus, Stephanie K.2002.Building The Strategic Plan: Find Analyze, And Present The Right Information. USA : Wiley.

Nazir, Moh. 2009. Metode Penelitian. Jakarta: Ghalia Indonesia
Rangkuti, Freddy. 2006. Analisis Swot Teknik Membedah Kasus Bisnis. Jakarta: P.T. Gramedia Pustaka Utama

Sugiyono. 2014. Analisis SWOT: Teknik Membedah Kasus Bisnis. Jakarta: PT Gramedia Pustaka Utama.

Roesmidi dan Risyanti, R. 2006. Pemberdayaan Masyarakat. Bandung: Alqaprint Jatinangor.

Rasyid, M. Ryaas. 1997. Makna Pemerintahan

Tinjauan Dari Segi Etika dan Kepemimpinan. Jakarta: PT Yarsif Watampone.

Sumaryadi, I Nyoman. 2005.Perencanaan

Pembangunan Daerah Otonom dan

Pemberdayaan Masyarakat. Jakarta: Citra Utama.

2010. Sosiologi Pemerintahan, Bogor: Ghalia Indonesia.

Soekanto, Soerjono. 2006. Sosiologi Suatu Pengantar. Jakarta: PT. Raja Grafindo Persada.

Sumodiningrat, Gunawan. 1999. Pemberdayaan Masyarakat dan Jaringan Pengaman Sosial. Jakarta: PT Gramedia Pustaka Utama.

Soebagyo. 1991. Desa Wisata di Bali: Tantangan dan Kesempatan dalam Kertas Kerja PPM. Yogyakarta: UGM.

Suharto, Edi. 2014. Membangun Masyarakat Memberdayakan Rakyat. Bandung: PT.Refika Aditama.

Salusu, J. 2008. Pengambilan Keputusan Strategis. Jakarta: Grasindo.

Sugiyono. 2009. Metode Penelitian Administrasi. Bandung: Alfabeta.

Sugiyono. 2013. Metode Penelitian Pendidikan

(Pendekatan Kuantitatif, Kualitatif, dan $R \& D$.Bandung: Alfabeta.

Suharsaputra, Uhar, 2012, Metode Penelitian, Bandung: Refika Aditiama.

Tjokroamidjojo, Bintoro. 1988. Teori dan Strategi 
Visioner - Vol. 12 \No. 2\April 2020:387-404

Pembangunan Nasional. Jakarta: CV. Haji Mas Agung.

Wasistiono, Sadu. 2003. Kapita Selekta

Penyelenggaraan Pemerintah Daerah.

Bandung: Fokusmedia.

Wasistiono, Sadu dan Simangunsong, Fernandes. 2014. Metodologi Ilmu Pemerintahan.

Jatinangor: IPDN Press. 